\title{
Managing Learners' Behaviours in Classroom through Negative Reinforcement Approaches
}

\author{
Jamalullail Abdul Wahab ${ }^{1}$, Azlin Norhaini Mansor ${ }^{1}$, Mohd Mahzan Awang ${ }^{1}$ \& Norazlina Mohamad Ayob ${ }^{1}$ \\ ${ }^{1}$ Faculty of Education, Universiti Kebangsaan Malaysia, Selangor, Malaysia \\ Correspondence: Jamalullail Abdul Wahab, Faculty of Education, Universiti Kebangsaan Malaysia, 43600 UKM \\ Bangi, Selangor, Malaysia. Tel: 60-3-8921-6398. E-mail: eda@ukm.my
}

\author{
Received: August 16, 2013 Accepted: October 14, 2013 Online Published: November 28, 2013 \\ doi:10.5539/ass.v9n16p61 URL: http://dx.doi.org/10.5539/ass.v9n16p61
}

\begin{abstract}
The present study aims to identify the types and levels of disruptive behaviours among students in classroom and the levels of negative reinforcement approaches practiced by teachers in managing and tackling these disruptive behaviours. A total of 119 teachers from four national secondary schools in Zone A, Miri, Sarawak were selected. Questionnaire was used to collect data and the data was analysed using descriptive and inferential statistics (one-way ANOVA). The research findings indicated that; (a) absenteeism especially entering classes late, and (b) defiance in classroom in which the learners refuse to join any social game activities conducted in classroom were among the highest disruptive behaviours displayed by the learners in classroom at the national secondary schools. The result of the present study also indicated the practice of negative reinforcement approach in the form of warning was higher than other forms of approaches (scolding and punishment). There was a significant difference with regard to the practice of negative reinforcement approach based on the teachers' years of teaching experience. Implications of the current study towards teaching practice and educational policy are also discussed.
\end{abstract}

Keywords: managing, learners' behaviours, negative reinforcement, discipline

\section{Introduction}

A good management of students' discipline in classroom may ensure an effective teaching and learning process in classroom. With a minimum number of students per class is 25 to 50 for 40 minutes or 80 minutes lesson, teachers nowadays are undoubtedly facing various challenges pertaining to students' attitudes and behaviours. Therefore, teachers' efficiency and wisdom in managing discipline in classroom is imperative to create a conducive learning environment that enhances the teaching and learning process. The main purpose of emphasising good discipline management in classroom is to facilitate students to fully utilise the teaching aids, learning materials as well as their peers in an organised way (Miller, 2006; Thornberg, 2009). In other words, good classroom management strategy contributes to assist students in developing their skills apart from it brings great impact in the long run (Rohaty et al., 1991; Leung \& Lam, 2003; Morrison, 2009). Teachers play a significant role in managing the discipline in classroom. Teachers that possess skills in managing discipline in classroom are capable in handling students' emotions and behaviours to ensure that they are able to participate in the teaching and learning process actively and consequently achieve the objectives of teaching and learning in classroom (Cameron, 1998; Charles, 2005; Morrison, 2009). Thus, this study examines discipline management in classroom from the aspect of the types of disruptive behaviours among students in classroom, the practice of teachers' negative reinforcement approach in managing and tackling these disruptive behaviours in classroom as well as to identify if there is any significant difference of various negative reinforcement approaches practiced by teachers (warning, scolding and punishment) on students that display disruptive behaviours based on the teachers' years of teaching experience (between junior and senior teachers).

\section{Problem Statement}

A conducive classroom milieu is very crucial in teaching and learning process. Good management of students' discipline in classroom by teachers will ensure a smooth and effective flow of the teaching and learning (Charles, 2005; Morrison, 2009). On the other hand, ineffective management of students' discipline in classroom may disrupt the lesson planned by teachers. Thus, teachers' skills and knowledge in dealing with disciplinary problems in classroom should be constantly enhanced. In other words, effective management of students' 
discipline in classroom is tremendously influenced by the teachers' efficiency in teaching, in dealing with the students as well as in managing the facilities available and physical state of the classroom (Mok, 2004; Morrison, 2009). According to Charles (2005), there are 13 types of disciplinary problems that occur in school. He further stated that the common disciplinary problems occur in the classroom are students are making noise, defiance, daydreaming, vandalism, walking aimlessly around the classroom without permission and refuse to participate in the teaching and learning process being carried out.

Teachers who are highly skilled in classroom management would be able to decrease disciplinary problems occur in classroom. Teachers as managers in handling their students may use various approaches in reducing the students' disciplinary problems in classroom for instance through the use of negative reinforcement approach (Morrison, 2009). Negative reinforcement is an approach that may give some unfavourable experiences to students that display disruptive behaviours through approaches such as punishment and warning in the effort to prevent the same negative behaviours being repeated (Ee Ah Ming, 2001; Leung \& Lam, 2003; Miller, 2006).

In order to ensure good discipline among students in classroom, teachers may effectively use the approach of punishment. Ee Ah Ming (2001) postulates that punishment is used to diminish and monitor disruptive behaviours displayed yet in the meantime it does not promote these negative behaviours among students as well as it helps to decrease the students' tendency in displaying such behaviours. The actions taken should be appropriate to the misbehaviours created and should be done through a mixture of approaches such as isolating problematic students from their group members, limiting their rights physically and giving them disparaging comments (Charles, 2005).

Managing students' discipline in classroom is not a simple task to be carried out especially when it involves majority of students who are academically poor (Ee Ah Ming, 2001). Failure in managing and controlling classroom can cause pressure among teachers which eventually may lead to burnout (Fernandez-Balboa, 1991). Having good personality, being dedicated and committed as well as possess intelligence and the ability to act rationally are to a great extent needed by a teacher in managing students' discipline in classroom to ensure a conducive classroom atmosphere that may lead to effective teaching and learning process (Cameron, 1998; Morrison, 2009).

The extent to which teachers are capable in managing discipline in classroom is very significant in making sure the aims and objectives of teaching and learning could be completely achieved. Research on managing students' discipline in classroom as the present study is vital since the findings may be of great help for teachers in school as guidelines in managing students' discipline in classroom effectively.

\section{Classroom Management Strategies}

Literature shows that many strategies can be used by teachers to manage classroom effectively (Awang et. al, 2013). This includes School-wide Positive Behaviour Intervention Support (Sugai \& Hornet, 2002), Culturally Responsive Classroom Management (Monroe, 2009), and Whole-school Approach (Rogers, 2007). School-wide Positive Behaviour Intervention Support model (Sugai et al., 2000; Sugai \& Hornet, 2002) posits that most students in school exhibit appropriate behaviour. Only a small percentage of students pose a very serious challenging behaviour. Due to this situation, the school management and teachers are supposed to have different approach in managing students' behaviour in school (Akin-Little, Little \& Laniti, 2007). However, teachers' ability to carry out various techniques and strategies in dealing problematic students is questionable. Monroe (2009) suggests the importance of socio-cultural values for effective classroom management. According to this model, teachers' knowledge in student's cultural background helps teachers to manage classroom effectively. This informs that some strategies may be effective in certain school but controversial in other schools. For instance, corporal punishment is acceptable in Malaysia but it is illegal in the United Kingdom. Therefore, socio-cultural values need to be considered in designing the school disciplinary rules and regulations. The Whole-school Approach (Roger, 2007) posits that effective classroom management require a holistic approach where the school should have a specific vision and mission for positive learning ecology. Irrespective of these approaches, the basic principles of managing classroom are revolving around two continuums namely positive reinforcement and negative reinforcement.

Positive reinforcement refers to techniques used to encourage positive behaviour in pupils. This includes the use of praise, encouragement and rewards (Akin-Little, Little \& Laniti, 2007). The basic principle of positive reinforcement is to encourage repetition of the desired behaviour in pupils. Positive reinforcement has a wide range of implementation in a school context. It involves how professionals communicate, interact, manage, deal and counsel pupils in a school. On the other hand, negative reinforcement refers to strategies used to eliminate or reduce undesired behaviour by taking away a negative condition as a consequence of the behaviour (Obenchain 
$\&$ Taylor, 2005). This includes time-away, physical punishment, suspension and dismissal (Awang, Jindal-Snape \& Barber, 2013).

\section{Research Purpose and Objectives}

The present study is intended to examine the types of disruptive behaviours among students in classroom and the practice of teachers' negative reinforcement approach in managing and tackling these disruptive behaviours in classroom. This study specifically embarks on the following objectives:

1) To identify the types and levels of students' disruptive behaviours in classroom.

2) To identify the levels of negative reinforcement approaches (warning, scolding and punishment) practiced by teachers in dealing with disruptive behaviours among students in classroom.

3) To determine the significant difference of various negative reinforcement approaches practiced by teachers (warning, scolding and punishment) on students that display disruptive behaviours based on teachers' years of teaching experience.

\section{Research Hypotheses}

There are four (4) null hypotheses constructed for this study:

Ho1 There is no significant difference with regard to the practice of negative reinforcement approach by teachers in the form of warning on students that display disruptive behaviours based on teachers' years of teaching experience.

Ho2 There is no significant difference with regard to the practice of negative reinforcement approach by teachers in the form of scolding on students that display disruptive behaviours based on teachers' years of teaching experience.

Ho3 There is no significant difference with regard to the practice of negative reinforcement approach by teachers in the form of punishment on students that display disruptive behaviours based on teachers' years of teaching experience.

\section{Research Methodology}

This study which was carried out using survey as its instrumentation employed a stratified random sampling method. The participants consisted of 119 teachers from four national secondary schools in Zone A, Miri, Sarawak. All of these participants were teachers who have continuously been involved in teaching and learning in classroom daily. The present study used questionnaire which was adapted and developed by the researcher based on the conceptual framework of the study, literature review as well as views and reviews of those who are experts in this research area. The questionnaire which was related to types of discipline and actions taken to control discipline in classroom was adapted from Seet (2005). The questionnaire used in this study comprised three parts: Part A was pertaining to respondents demographic details, Part B was regarding disciplinary problems that occur in classroom and Part $\mathrm{C}$ was related to types of negative reinforcement taken on students that cause disciplinary problem in classroom. The respondents marked their responses on a 5-point Likert scale for the items in the questionnaire. Data gathered were analysed using SPSS 11.5.

\section{Research Findings}

The presentation of the research findings is categorized into two parts namely descriptive and inferential analyses. Descriptive analysis was used to explain objectives (1) and (2), while ANOVA was employed to expound objective (3). 


\subsection{Demographic Profile of Respondents}

Table 1. Distribution of respondents by gender

\begin{tabular}{llll}
\hline Demographic Profile & & Frequency & Percent (\%) \\
\hline Gender & Male & 32 & 26.9 \\
& Female & 87 & 73.1 \\
& Total & $\mathbf{1 1 9}$ & $\mathbf{1 0 0 . 0}$ \\
Ethnic & Malay & 64 & 53.9 \\
& Chinese & 20 & 16.8 \\
& Indian & 3 & 2.5 \\
& Others & 32 & 26.9 \\
& Total & $\mathbf{1 1 9}$ & $\mathbf{1 0 0 . 0}$ \\
\hline
\end{tabular}

The respondents of this study consisted of 119 teachers from four national secondary schools in Zone A, Miri, Sarawak. All of these participants were teachers who have continuously been involved in teaching and learning in daily classroom. Table 1 indicates the number of respondents based on gender. 87 respondents which are equal to $73.1 \%$ were female teachers while the remaining 32 respondents $(26.9 \%)$ were male teachers. Based on the ethnicity category, 64 respondents which are an equivalent to $53.9 \%$ were Malays. This is followed by 32 respondents which are equal to $26.9 \%$ were teachers from other races that included the Sarawak Bumiputera (Aborigine). 20 respondents or $16.8 \%$ were Chinese while the remaining 3 respondents $(2.5 \%)$ were Indians.

Table 2. Distribution of respondents by years of teaching experience

\begin{tabular}{lll}
\hline Years of Teaching & Frequency & Percent (\%) \\
\hline Less than 1 year & 38 & 31.9 \\
1 to 5 years & 30 & 25.2 \\
6 to 10 years & 21 & 17.6 \\
11 years and above & 30 & 25.2 \\
Total & $\mathbf{1 1 9}$ & $\mathbf{1 0 0 . 0}$ \\
\hline
\end{tabular}

With reference to Table 2, the distribution of respondents by years of teaching shows that 38 respondents (31.9\%) had less than one year of teaching experience while 30 respondents or $25.2 \%$ had one to five years of teaching experience. This is followed by another 30 respondents that represent $25.2 \%$ of the total population studied that had more than 11 years of teaching experience while the other 21 respondents $(17.6 \%)$ had six to 10 years of teaching experience.

\subsection{Types and Levels of Students' Disruptive Behaviours in Classroom}

\subsubsection{Making Verbal Disturbance or Noise during Teaching Activity}

The research findings obtained from the respondents pertaining to types of verbal disturbances created during teaching activity that affect the types of negative reinforcement approaches practiced by teachers were interpreted using Jamil Mean Score (1993) as indicated in Table 3.

Table 3. Mean score interpretation

\begin{tabular}{ll}
\hline Mean Score & Interpretation \\
\hline $1.00-2.33$ & Low \\
$2.34-3.66$ & Moderate \\
$3.67-5.00$ & High \\
\hline
\end{tabular}

Source: Adapted from Jamil (1993) 
Table 4 demonstrates the mean and standard deviation of each item related to disruptive behaviour involving verbal disturbances or noise created during teaching activity. In general the level of disruptive behaviours involving verbal disturbances created during teaching activity was moderate in which the total mean score was 2.600 and the standard deviation was 1.131. The mean score of talking while teacher is teaching was moderate that was 3.227 followed by the action of laughing loudly with other students that was $\mathrm{M}=2.874$ (moderate). The action of making verbal disturbance in the form of whistling while the teacher is teaching was low with a mean score of 2.294 .

Table 4. Means and standard deviations of making verbal disturbance or noise during teaching activity occur in classroom

\begin{tabular}{llll}
\hline No. & Item & Mean & SD \\
\hline 1 & Talking while teacher is teaching. & 3.227 & 1.145 \\
2 & Asking too many questions that disrupt teachers' concentration to teach. & 2.344 & 1.077 \\
3 & Singing while teacher is teaching. & 2.429 & 1.176 \\
4 & Laughing loudly with other students. & 2.874 & 1.038 \\
5 & Whistling while teacher is teaching. & 2.294 & 1.203 \\
6 & Purposely dropping items on the floor with the intention to create noise. & 2.403 & 1.145 \\
& Total Score & $\mathbf{2 . 6 0 0}$ & $\mathbf{1 . 1 3 1}$ \\
\hline
\end{tabular}

\subsubsection{Disrespectful Problems}

Table 5 indicates the mean and standard deviation of each item with reference to disrespectful problems that occur in classroom. In general, the level of disrespectful problems that occur in classroom was moderate $(\mathrm{M}=2.771, \mathrm{SD}=1.004)$. Problem involving students who are not properly attired was at a moderate level with a mean score of 3.286. This is followed by keeping long and messy hair $(\mathrm{M}=3.017)$ as well as curling lips when reprimanded by teacher $(\mathrm{M}=2.412)$ in which both were at moderate level.

Table 5. Means and standard deviations of disrespectful problems occur in classroom

\begin{tabular}{rlll}
\hline No. & Item & Mean & SD \\
\hline 1. & Not properly attired. & 3.286 & 1.194 \\
2. & Keeping long and messy hair. & 3.017 & 0.048 \\
3. & Keeping long and uncut nails. & 2.655 & 1.160 \\
4. & Using offensive language towards other students. & 2.639 & 0.936 \\
5. & Curling lips when reprimanded by teacher. & 2.412 & 0.986 \\
6. & Rolling eyes or snorting or pulling faces when reprimanded by teacher. & 2.613 & 0.921 \\
7. & Refuse to sit down while teacher is teaching. & 2.513 & 0.937 \\
8. & Staring out of the classroom while teacher is teaching. & 3.143 & 0.932 \\
9. & Shoving chair and desk while teacher is teaching. & 2.748 & 1.277 \\
10. & Swearing at other students. & 2.521 & 1.294 \\
11. & Shouting at other students. & 2.789 & 1.049 \\
12. & Making fun of other students. & 2.941 & 1.002 \\
13. & Making fun of other students by calling them using impolite/negative & 3.000 & 0.957 \\
14. & names. & & \\
15. & Felling at teacher. & 2.605 & 1.230 \\
& Total Score & 2.681 & 1.134 \\
\hline
\end{tabular}




\subsubsection{Absenteeism}

An overview of the results in Table 1.6 shows that the level of absenteeism that occurs in classroom in general was at a moderate level with a mean score of 2.980 and a standard deviation of 1.063 . The act of entering class late was moderate $(\mathrm{M}=3.471)$ followed by skipping classes with a mean score of 2.857 . In addition, the act of leaving classroom without permission also appeared to be moderate $(\mathrm{M}=2.613)$.

Table 6. Means and standard deviations of absenteeism problems in classroom

\begin{tabular}{llll}
\hline No. & Item & Mean & SD \\
\hline 1. & Skipping classes & 2.857 & 1.091 \\
2. & Leaving classroom without permission & 2.613 & 1.026 \\
3. & Entering class late & 3.471 & 1.072 \\
& Total Score & $\mathbf{2 . 9 8 0}$ & $\mathbf{1 . 0 6 3}$ \\
\hline
\end{tabular}

\subsubsection{Vandalism}

Based on Table 7, it is noted that vandalism that occurs in classroom seemed to be at a moderate level with a total mean score of 2.800 and a standard deviation of 0.996 . The act of doodling desk or book was moderate with a mean score of 3.260 followed by dragging chair $(\mathrm{M}=3.210)$ which was moderate as well. Additionally, the act of tearing up own book or others' was also at a moderate level with a mean score of 2.118 .

Table 7. Means and standard deviations of vandalism in classroom

\begin{tabular}{llll}
\hline No. & Item & Mean & SD \\
\hline 1. & Doodling desk or book & 3.260 & 0.995 \\
2. & Leaning on the back legs of a chair & 3.008 & 1.061 \\
3. & Dragging chair & 3.210 & 0.955 \\
4. & Knocking on desk & 2.950 & 0.928 \\
5. & Ripping up other students' work & 2.244 & 0.956 \\
6. & Tearing up own book or other students' & 2.118 & 1.082 \\
& Total Score & $\mathbf{2 . 8 0 0}$ & $\mathbf{0 . 9 9 6}$ \\
\hline
\end{tabular}

\subsubsection{Gangsterism}

As shown in Table 8, gangsterism that occurs in classroom was at a moderate level $(\mathrm{M}=2.407, \mathrm{SD}=1.067)$. The action of seizing or stealing others' belongings was moderate with a mean score of 2.613 followed by the action of throwing objects to others $(\mathrm{M}=2.588)$ as well as tugging on others' clothes with a mean score of 2.546. In contrast, the action of receiving bribe was low $(\mathrm{M}=1.908)$.

Table 8. Means and standard deviations of gangsterism in classroom

\begin{tabular}{llll}
\hline No. & Item & Mean & SD \\
\hline 1. & Physically hurting others & 2.412 & 1.153 \\
2. & Threatening others & 2.387 & 1.074 \\
3. & Receiving bribe & 1.908 & 0.965 \\
4. & Tugging on others' clothes & 2.546 & 1.155 \\
5. & Seizing or stealing others' belongings & 2.613 & 1.018 \\
6. & Throwing objects to others & 2.588 & 1.182 \\
7. & Pinching others & 2.395 & 0.922 \\
& Total Score & $\mathbf{2 . 4 0 7}$ & $\mathbf{1 . 0 6 7}$ \\
\hline
\end{tabular}




\subsubsection{Defiance}

As depicted in Table 9, it is noted that problems related to defiance were at a moderate level with a mean score of 3.135 and a standard deviation of 1.092. The action of refusing to concentrate on or cooperate in classroom activities had a moderate mean score of 3.437. This is followed by refuse to get involved in classroom activities $(\mathrm{M}=3.378)$ and refuse to join any social game activities conducted in classroom $(\mathrm{M}=3.344)$. Besides, stealing or dispossessing others' belongings was also at a moderate level $(\mathrm{M}=2.698)$.

Table 9. Means and standard deviations of defiance in classroom

\begin{tabular}{llll}
\hline No. & Item & Mean & SD \\
\hline 1. & Sleeping while teacher is teaching. & 3.294 & 1.052 \\
2. & Refuse to join any activities conducted in classroom. & 3.378 & 0.854 \\
3. & Refuse to join any social game activities conducted in classroom. & 3.344 & 1.100 \\
4. & Refuse to concentrate on or cooperate in activities conducted in classroom. & 3.437 & 1.102 \\
5. & Refuse to share equipment with others. & 2.773 & 1.196 \\
6. & Walking around aimlessly in classroom. & 2.933 & 1.198 \\
7. & Jesting while running after one another with other student in classroom. & 3.025 & 1.238 \\
8. & Drinking during teaching and learning session. & 3.176 & 1.132 \\
9. & Littering. & 3.294 & 0.977 \\
10. & Eating candies or chewing gum. & 3.235 & 1.132 \\
11. & Complaining while completing tasks given by teacher. & 3.294 & 0.857 \\
12. & Keeping silent or refuse to respond to teacher although the teacher is & 2.882 & 1.051 \\
& asking for students' response individually. & & \\
13. & Stealing or dispossessing others' belongings. & 2.698 & 1.305 \\
& Total Score & $\mathbf{3 . 1 3 5}$ & $\mathbf{1 . 0 9 2}$ \\
\hline
\end{tabular}

\subsubsection{Sexual Harassment Problems}

With regard to Table 10, the total mean score of 1.189 and a standard deviation of 0.489 signify that sexual harassment problems that occur in classroom were moderate. It is discovered that the action of harassing student from the opposite gender was higher $(\mathrm{M}=1.201)$ than of the same gender $(\mathrm{M}=1.176)$.

Table 10. Means and standard deviations of sexual harassment problems occur in classroom

\begin{tabular}{llll}
\hline No. & Item & Mean & SD \\
\hline 1. & Sexually harassing student from the opposite gender. & 1.201 & 0.497 \\
2. & Sexually harassing student of similar gender. & 1.176 & 0.481 \\
& Total Score & $\mathbf{1 . 1 8 9}$ & $\mathbf{0 . 4 8 9}$ \\
\hline
\end{tabular}

\subsection{Negative Reinforcement Approaches Practiced by Teachers in Dealing with Disruptive Behaviours in Classroom}

\subsubsection{Warning}

Table 11 indicates the mean score and standard deviation of each item with regard to the practice of negative reinforcement approach in the form of warning. Generally, the total mean score of the practice of negative reinforcement approach in the form of warning was high $(\mathrm{M}=4.074)$ with a standard deviation of 1.415 . The approach of demonstrating and explaining to the students of the appropriate behaviours to be displayed whenever any of the students misbehaves had a high mean score of 4.571 followed by informing the students that the displayed behaviours are inappropriate in a subtle way with a mean score of 4.193. Apart from that, the teachers' approach at developing the students' behaviours by continuously giving encouragement to them to display good 
behaviours at all times was also at a high level with a mean score of 4.184. On the contrary, the approach of the teachers telling the students of the disruptive behaviours committed by their friends and advising them to avoid doing so was at a moderate level with a mean score of 3.546 .

Table 11. Means and standard deviations of negative reinforcement approaches in the form of warning in dealing with disruptive behaviours occur in classroom

\begin{tabular}{|c|c|c|c|}
\hline No. & Item & Mean & SD \\
\hline 1. & $\begin{array}{l}\text { Informing the students that the displayed behaviours are inappropriate in a } \\
\text { subtle way. }\end{array}$ & 4.193 & 0.740 \\
\hline 2. & $\begin{array}{l}\text { Demonstrating and explaining to the students of the appropriate } \\
\text { behaviours to be displayed whenever any of the students misbehaves. }\end{array}$ & 4.571 & 4.738 \\
\hline 3. & $\begin{array}{l}\text { The teachers telling the students of the disruptive behaviours committed } \\
\text { by their friends and advising them to avoid doing so. }\end{array}$ & 3.546 & 1.133 \\
\hline 4. & $\begin{array}{l}\text { Informing the students the displayed behaviours are inappropriate and later } \\
\text { showing the appropriate ones. }\end{array}$ & 3.983 & 0.823 \\
\hline 5. & $\begin{array}{l}\text { Developing the students' behaviours by continuously giving } \\
\text { encouragement to them to display good behaviours at all times. }\end{array}$ & 4.184 & 0.853 \\
\hline 6. & $\begin{array}{l}\text { Informing the students that the teachers would be very disappointed with } \\
\text { students who display disruptive behaviours. }\end{array}$ & 3.924 & 0.884 \\
\hline \multirow[t]{2}{*}{7.} & $\begin{array}{l}\text { Warn the students who display disruptive behaviours before penalising } \\
\text { them. }\end{array}$ & 4.118 & 0.738 \\
\hline & Total Score & 4.074 & 1.415 \\
\hline
\end{tabular}

\subsubsection{Scolding/Threatening/Complaining/Coercion}

Table 12 shows the mean score and standard deviation of each item with regard to the practice of negative reinforcement approach in the form of scolding or threatening or complaining or coercion towards students who display disruptive behaviours. The practise of this approach was moderate as indicated by the total mean score of 2.394 and a standard deviation of 1.053. The approach of looking at the students who display disruptive behaviours with frustration and anger was at a moderate level with a mean score of 2.983 followed by threatening the students that those who repeat the same disruptive behaviours will be punished $(\mathrm{M}=2.938)$. The next popular approach practised was scolding the students who display disruptive behaviours individually with a mean score of 2.932 while the act of cursing at the students with disruptive behaviour was low with a mean score of 1.285 .

Table 12. Means and standard deviations of negative reinforcement approaches in the form of scolding/threatening/complaining/coercion in dealing with disruptive behaviours occur in classroom

\begin{tabular}{llll}
\hline No. & Item & Min & S.P \\
\hline 1. & Scolding students who display disruptive behaviours individually. & 2.932 & 1.307 \\
2. & Cursing at students who display disruptive behaviours. & 1.285 & 0.749 \\
3. & Yelling at disruptive behaviours displayed right away. & 2.613 & 1.180 \\
4. & Looking at the students who display disruptive behaviours with frustration & 2.983 & 0.883 \\
& & \\
and anger. & 1.823 & 0.980 \\
6. & Humiliating the students who display disruptive behaviours. & 2.529 & 1.247 \\
7. & Keeping silent and wait for the disruptive behaviours displayed to end. & 1.038 \\
8. & Threatening the students that those who repeat the same disruptive & 2.938 \\
9. & Bringing the students to see the principal or the discipline teacher. & 2.344 & 1.100 \\
& Forcing the students to apologise. & 2.101 & 0.993 \\
\hline
\end{tabular}




\subsubsection{Penalty/Punishment}

An overview of the results in Table 13 shows that the practice of negative reinforcement approach in the form of punishment in general was low with a total mean score of 2.042 and a standard deviation of 1.012. The action of ordering the students to clean the classroom or asking them to help the teachers was at a moderate level $(\mathrm{M}=3.067)$ and the approach of not giving any special treatment towards students who misbehave was also moderate with a mean score of 2.908. The approach of disallowing the students to eat their favourite food such as sweets was at a moderate level $(\mathrm{M}=2.832)$ while the action of calling the students with names of disliked animals in the classroom was low with a mean score of 1.101 .

Table 13. Means and standard deviations of negative reinforcement approaches in the form of punishment in dealing with disruptive behaviours occur in classroom

\begin{tabular}{|c|c|c|c|}
\hline No. & Item & Mean & SD \\
\hline 1. & Disallowing the misbehaved students to do their favourite activities. & 2.513 & 1.141 \\
\hline 2. & Disallowing the misbehaved students to play during recess. & 1.580 & 0.979 \\
\hline 3. & $\begin{array}{l}\text { Disallowing the misbehaved students to join any activities conducted in } \\
\text { classroom. }\end{array}$ & 1.563 & 0.980 \\
\hline 4. & $\begin{array}{l}\text { Disallowing the misbehaved students to eat their favourite food such as } \\
\text { sweets. }\end{array}$ & 2.832 & 1.514 \\
\hline 5. & Not giving any special treatment towards misbehaved students. & 2.908 & 1.058 \\
\hline 6. & $\begin{array}{l}\text { Seizing or throwing away the belongings of students who display } \\
\text { disruptive behaviours. }\end{array}$ & 1.748 & 1.099 \\
\hline 7. & $\begin{array}{l}\text { Giving an unfavourable or painful punishment after displaying any } \\
\text { disruptive behaviour. }\end{array}$ & 1.874 & 1.038 \\
\hline 8. & Calling the students with names of disliked animals in the classroom. & 1.101 & 0.354 \\
\hline 9. & $\begin{array}{l}\text { Separating the misbehaved students to other places without talking to them } \\
\text { or looking at them or changing them to a more fun activity. }\end{array}$ & 1.530 & 0.900 \\
\hline 10. & $\begin{array}{l}\text { Ordering the students to clean the classroom or asking them to help the } \\
\text { teachers. }\end{array}$ & 3.067 & 1.014 \\
\hline 11. & Ignoring the students who display disruptive behaviours. & 1.958 & 1.003 \\
\hline 12. & Penalising the misbehaved students physically such as a push-up. & 2.084 & 1.139 \\
\hline 13. & Caning the students on their hands. & 1.849 & 1.147 \\
\hline 14. & $\begin{array}{l}\text { Penalising the students by ordering them to stand still throughout the } \\
\text { lesson. }\end{array}$ & 2.286 & 0.949 \\
\hline 15. & Penalising students by ordering them to copy out sentences. & 1.689 & 0.918 \\
\hline \multirow[t]{2}{*}{16.} & Giving extra work as a penalty. & 2.092 & 0.957 \\
\hline & Total Score & 2.042 & 1.012 \\
\hline
\end{tabular}

7.4 The Practices of Different Negative Reinforcement Approaches (Warning, Scolding and Punishment) on Students with Disruptive Behaviours Based on Teachers' Years of Teaching Experience

Ho1 There is no significant difference with regard to the practice of negative reinforcement approach by teachers in the form of warning on students that display disruptive behaviours based on teachers' years of teaching experience.

Table 14 indicates the difference in the mean scores of negative reinforcement approach in the form of warning practiced in classroom by teachers based on the teachers' years of teaching experience. Based on the one-way ANOVA test performed, it was noted that $\mathrm{F}=4.333, p(0.006)<0.05$. Therefore, Ho1 was rejected as the $p$-value was significant. This indicated that there was a significant difference with regard to the practice of negative reinforcement approach by teachers in the form of warning on students that display disruptive behaviours based on teachers' years of teaching experience. 
Table 14. ANOVA between the practices of negative reinforcement approach (warning) by teachers in dealing with disruptive behaviours in classroom and teachers' years of teaching experience

\begin{tabular}{llllll}
\hline & Years of Teaching & N & Mean & F & Sig(P) \\
\hline Negative Reinforcement & Less than 1 year & 38 & 3.744 & 4.333 & .006 \\
Approach (Warning) & 1 to 5 years & 30 & 4.152 & & \\
& 6 to 10 years & 21 & 4.204 & & \\
& 11 years and above & 30 & 4.205 & & \\
Total & & $\mathbf{1 1 9}$ & $\mathbf{4 . 0 7 6}$ & &
\end{tabular}

Significance level at $<0.05$

Ho2 There is no significant difference with regard to the practice of negative reinforcement approach by teachers in the form of scolding on students that display disruptive behaviours based on teachers' years of teaching experience.

Table 15 demonstrates the difference in the mean scores of negative reinforcement approach in the form of scolding practiced in classroom by teachers based on the teachers' years of teaching experience. Based on the one-way ANOVA test performed, it was noted that $\mathrm{F}=7.894, p(0.000)<0.05$. Therefore, Ho2 was rejected as the $p$-value was significant. This indicated that there was a significant difference with regard to the practice of negative reinforcement approach by teachers in the form of scolding on students that display disruptive behaviours based on teachers' years of teaching experience.

Table 15. ANOVA between the practices of negative reinforcement approach (scolding) by teachers in dealing with disruptive behaviours in classroom and teachers' years of teaching experience

\begin{tabular}{llllll}
\hline & Years of Teaching & N & Mean & F & Sig(P) \\
\hline Negative Reinforcement & Less than 1 year & 38 & 2.222 & 7.894 & .000 \\
Approach (Scolding) & 1 to 5 years & 30 & 2.752 & & \\
& 6 to 10 years & 21 & 2.321 & & \\
& 11 years and above & 30 & 2.241 & & \\
Total & & $\mathbf{1 1 9}$ & $\mathbf{2 . 3 8 4}$ & & \\
\hline
\end{tabular}

Significance level at $<0.05$

Ho3 There is no significant difference with regard to the practice of negative reinforcement approach by teachers in the form of punishment on students that display disruptive behaviours based on teachers' years of teaching experience.

Table 16 indicates the difference in the mean scores of negative reinforcement approach in the form of punishment practiced in classroom by teachers based on the teachers' years of teaching experience. Based on the one-way ANOVA test performed, it was noted that $\mathrm{F}=4.735, p(0.004)<0.05$. Thus, Ho3 was rejected as the $p$-value was significant. This indicated that there was a significant difference with regard to the practice of negative reinforcement approach by teachers in the form of punishment on students that display disruptive behaviours based on teachers' years of teaching experience. 
Table 16. ANOVA between the practices of negative reinforcement approach (punishment) by teachers in dealing with disruptive behaviours in classroom and teachers' years of teaching experience

\begin{tabular}{llllll}
\hline & Years of Teaching & N & Mean & F & Sig(P) \\
\hline Negative Reinforcement & Less than 1 year & 38 & 1.914 & 4.735 & .004 \\
Approach (Punishment) & 1 to 5 years & 30 & 2.142 & & \\
& 6 to 10 years & 21 & 2.298 & & \\
& 11 years and above & 30 & 1.925 & & \\
Total & & $\mathbf{1 1 9}$ & $\mathbf{2 . 0 7 0}$ & & \\
\hline
\end{tabular}

Significance level at $<0.05$

\section{Conclusion and Discussion}

The findings indicate that the most prevailing disciplinary problem occurs in classroom is truancy that is entering classes late with a mean score of 3.471. This is followed by refuse to concentrate on or cooperate in activities conducted in classroom with a mean score of 3.437 and not properly attired $(\mathrm{M}=3.286)$. All these are examples of several disciplinary problems from 13 major disciplinary problems suggested by Charles (2005). The findings further indicate that the most dominant disruptive behaviours occur in classroom are closely related to the attitude and personality of the students. This probably is due to lack of moral values instilled and practiced apart from having lack of self-awareness among the students themselves (Thornberg, 2009).

This study also illustrates the most frequent negative reinforcement approaches practiced by teachers in dealing with disruptive behaviours in classroom are demonstrating and explaining to the students of the appropriate behaviours to be displayed whenever any of the students misbehaves with a mean score of 4.571 which confirmed the findings of Cameron (1998) and Leung and Lam (2003). This is followed by ordering the students to clean the classroom or asking them to help the teachers $(\mathrm{M}=3.067)$ and the approach of looking at the students who display disruptive behaviours with frustration and anger with a mean score of 2.983. These findings demonstrate that the approaches practised by teachers are more likely to be on diplomatic basis (Miller, 2006). Teachers are more tolerant by taking actions which are aligned with human rights and qualities as well as nature of parents (Sheppard, 2009). In addition, this study further renders in which teachers as classroom managers should know when exactly to punish their students to avoid unnecessary or disparaging punishment. Teachers who are good in disciplining their students believe that punishment is suitable for repeated misbehaviour. However, if the students show some improvements in behaviours, the punishment should be discontinued. This finding corresponds with Robertson (1996) and Charles (2005) that posits punishment should be the last option in dealing with students' disruptive behaviours.

This study further denotes there is a statistically significant difference with reference to the three different negative reinforcement approaches (warning, scolding, and punishment) practised by teachers in dealing with disruptive behaviours in classroom based on the teachers' years of teaching experience. Based on the one-way ANOVA test performed, it was noted that $\mathrm{F}=4.333, p(0.006)<0.05$ for warning approach, $\mathrm{F}=7.894, p(0.000)<$ 0.05 for scolding approach and $\mathrm{F}=4.735, p(0.004)<0.05$ for punishment approach. Based on these results, they showed that different negative reinforcement approach was practised by teachers based on their years of teaching experience.

\section{Implication}

The most prevailing disciplinary problem occurs in classroom is truancy that is coming late to classes followed by refuse to concentrate on or cooperate in activities conducted in classroom. These disruptive behaviours which take place in classroom are closely related to the attitude and personality of the students. Lack of moral values instilled and practiced among them contributes to this occurrence. Normally, the teachers would employ negative reinforcement approach in the form of warning (at a high level) as well as positive reinforcement approach in handling disruptive behaviours in classroom at national secondary schools. The teachers' years of teaching experience influences the negative approaches exercised. There is a significant difference with reference to the three different negative reinforcement approaches (warning, scolding, and reprimanding) practised by the teachers in dealing with disruptive behaviours in classroom based on the teachers' years of teaching experience. The findings of this study indicate that there is a difference in the approaches practised in managing disruptive behaviours in classroom between junior and senior teachers. The findings of this study are beneficial to 
administrators and teachers in schools as guidelines to improve the effectiveness of teaching and learning process in classroom by effectively dealing with disruptive behaviours. Positive behaviour enhancement approach is suggested to be a pillar for managing students' behaviour in school as past studies revealed that it has a positive impact on students' psychological well-being. Besides, the findings are also of use to State Education Department and the Ministry of Education in planning and implementing programmes or courses to enhance teachers' professionalism from the aspect of disruptive behaviours management in classroom.

\section{References}

Ahmad, J. (1993). Tinjauan mengenai kekangan-kekangan dalam pelaksanaan sains KBSM di sekolah-sekolah menengah di Negeri Kedah.

Akin-Little, K. A., Little, S. G., \& Laniti, M. (2007). Teachers' Use of Classroom Management Procedures in the United States and Greece: A Cross-Cultural Comparison. School Psychology International, 28(1), 52-63. http://dx.doi.org/10.1177/0143034307075680

Awang, M. M., Ahmad, A. R., Wahab, J. L. A., \& Mamat, N. (2013). Effective Teaching Strategies to Encourage Learning Behaviour. IOSR Journal of Humanity \& Social Sciences, 8(2), 35-40. http://dx.doi.org/10.9790/0837-0823540

Awang, M. M., Jindal-Snape, D., \& Barber, T. (2013). A Documentary Analysis of the Government's Circulars on Positive Behavior Enhancement Strategies. Asian Social Science, 9(5), 203-208. http://dx.doi.org/10.5539/ass.v9n5p203

Cameron, R., J. (1998). School discipline in the United Kingdom: Promoting classroom behaviour which encourages effective teaching and learning. School Psychology Review, 27(1), 33-44.

Charles, C. (2005). Building classroom discipline (6th ed.). Boston: Pearson Education.

Chein, S. M. (2005). Satu Kajian Berkenaan Pengurusan Disiplin Dalam Bilik Darjah Menurut Persepsi Guru Pra Sekolah. Tesis Sarjana, Universiti Kebangsaan Malaysia, Bangi.

Doyle, W. (1986). Classroom Organisation and Management. In M. C. Wittrock (Ed.), Handbook of Researcher Teaching. New York: Mc.Millan.

Fernandez-Balboa, J. M. (1991). Physical Education Student Teacher's Reflections, Beliefs, and Actions Regarding Pupils' Misbehavior. Journal of Teaching in Physical Education.

Leung, C. M., \& Lam, S. f. (2003). The effects of regulatory focus on teachers' classroom management strategies and emotional consequences. Contemporary Educational Psychology, 28(1), 114-125. http://dx.doi.org/10.1016/S0361-476X(02)00009-7

Majzub, R. M., Meerah, T. S. M., Karim, F., \& Hassan, A. J. (1991). Disiplin Dalam Pendidikan. Kuala Lumpur: Nurin Enterprise.

Meng, E. A. (2001). Pedagogi II (Edisi Kedua). Shah Alam: Penerbit Fajar Bakti Sdn. Bhd.

Miller, A. (2006). Teachers, parents and classroom Behaviour. A psychosocial approach. Glasgow: Open University Press.

Monroe, C. R. (2009). Teachers Closing the Discipline Gap in an Urban Middle School. Urban Education, 44(3), 322-347. http://dx.doi.org/10.1177/0042085908318716

Morrison, M. (2009). Leadership and Learning. New York: Information Age Publishing.

Obenchain, K. M., \& Taylor, S. S. (2005). Behavior Management: Making It Work in Middle and Secondary. The Clearing House: A Journal of Educational Strategies, Issues and Ideas, 79(1), 7-11. http://dx.doi.org/10.3200/TCHS.79.1.7-11

Rogers, B. (2007). Behaviour Management: A whole-school Approach (2nd ed.). London: Paul Chapman Publishing.

Sang, M. S. (2004). Ilmu Pendidikan Untuk KPLI. Subang Jaya: Kumpulan Budiman Sdn. Bhd.

Sheppard, A. (2009). A school attendance and attainment: poor attenders' perceptions of schoolwork and parental involvement in their education. British Journal of Special Education, 36(2), 104-111. http://dx.doi.org/10.1111/j.1467-8578.2009.00413.x

Sugai et al. (2000). Applying Positive Behavioral Support and Functional Behavioral Assessment in Schools. Journal of Positive Behavioral Interventions, 2, 131-143. http://dx.doi.org/10.1177/109830070000200302 
Sugai, G., \& Hornet, R. (2002). The Evolution of Discipline Practices: School-Wide Positive Behavior Supports. Child and Family Behavior Therapy, 24, 23-50. http://dx.doi.org/10.1300/J019v24n01_03

Thornberg, R. (2009). The moral construction of the good pupil embedded in school rules. Education, citizenship and social justice, 4(3), 245-261. http://dx.doi.org/10.1177/1746197909340874

\section{Copyrights}

Copyright for this article is retained by the author(s), with first publication rights granted to the journal.

This is an open-access article distributed under the terms and conditions of the Creative Commons Attribution license (http://creativecommons.org/licenses/by/3.0/). 